\title{
The Micro, Small, and Medium-Sized Enterprises and Its Role in the Economic Development of a Country
}

\author{
Jorge Morales Pedraza ${ }^{1}$ \\ ${ }^{1}$ Senior Researcher and Co-founder, Morales Project Consulting, Vienna, Austria \\ Correspondence: Jorge Morales Pedraza, Morales Project Consulting, Vienna, Austria. E-mail: \\ jmorales47@hotmail.com; jmp@moralesconsulting.at
}

Received: January 3, 2021 Accepted: February 10, 2021 Online Published: February 20, 2021

doi:10.5430/bmr.v10n1p33 URL: https://doi.org/10.5430/bmr.v10n1p33

\begin{abstract}
Undoubtedly, micro, small, and medium-sized enterprises (MSMEs) play a central role in many countries' economic development. They are a major source of entrepreneurial skills, innovation, and employment account for most businesses worldwide. MSMEs are important contributors to job creation and global economic development, representing $90 \%$ of businesses and more than $50 \%$ of employment worldwide.
\end{abstract}

Keywords: micro enterprises, small enterprises, medium-sized enterprises, large corporation, large companies, emerging economies, developed economies, developing country, emerging economies, developed country

\section{Introduction}

The micro, small, and medium company or MSME is an independent firm with specific working and financial boundaries established by the states or group of states with particular logics, cultures, interests, and a business spirit. According to Liberto (2020), MSMEs are firms that maintain incomes, assets, and several workers below a certain threshold established by law in each country or group of countries. Each country has its own definition of what constitutes an MSME. This type of firm is often considered to be the heartbeat of both developing and developed economies. Many people in developing economies are working in MSMEs, contributing roughly $45 \%$ of total employment and $33 \%$ of GDP in these countries, according to the Organization for Economic Co-operation and Development (OCED).

Undoubtedly, MSMEs play a central role in many countries' economic development. They are a major source of business skills, innovation, and employment (The new SME definition. User guide and model declaration, 2018).

What is the importance of MSMEs? Through the MSMEs, which represent more than $95 \%$ of all companies in most countries, opportunities can be found to promote the development of the country's economy. If the MSMEs have the elements to maintain themselves and grow, they will contribute significantly to their economies.

Compared with large corporations, MSMEs have great advantages. These advantages are, among others, the following:

- Agility in decision-making. While large companies, the bureaucracy, and coordination between different area make the decision-making process slow, MSME companies can do it much faster;

- Closer to customers. MSMEs can better understand their client's needs, increase satisfaction, and, therefore, loyalty;

- Greater flexibility and adaptability. Due to their size, MSMEs can adapt more easily to eventual market changes, modifying their structure and processes depending on the needs of the new market;

- Relationship and work environment. While in large companies, the worker is only a number, in MSMEs, each worker is fundamental to the company's exit, and due to their size, it is easier to generate and strengthen ties among them.

- Horizontal communication. In MSMEs, it is possible to establish direct and transversal communication between all of the company's workers, something impossible to achieve in a large company due to the hierarchical levels and the existence of various departments;

- Their possibility of specializing in each market niche offers direct attention. 
MSMEs' greatest advantage is their capacity to introduce necessary changes in their production structure quickly to produce new products that reflect better market new needs. This capacity to change the production structure in a large company is much difficult to be carried out due to the high number of employees, a more complex production structure, and a huge amount of capital invested.

\subsection{Main Characteristics of Each Type of MSMEs}

The main characteristics associated with each type of MSMEs are the following:

- Microenterprises add value to the economy of many countries all over the world by generating micro-businesses, better adjusting revenues, and reducing the overall cost of doing business. The number of microentrepreneurs is high because they often do not find adequate training or formal jobs available to them. Microenterprises very often offer products and services specifically for local areas. This type of company provides food products, household goods, and specialized demand in repair or care services typical to the area or regions where they are located.

- A small business is a company that employs a low number of workers and does not have a large volume of sales. In technical terms, this is an independently operated and managed company and has limited size and revenue based on the economic sector it operates. These companies are usually privately owned sole proprietorships or business partnerships. There are small businesses in almost every economic sector in a given country. They can range from convenience stores to modest manufacturing plants. Some examples of this type of enterprise might be a local bakery, private restaurants, law firms, dry cleaners, engineering, architecture firms, and consultant companies. Small businesses also vary in terms of size, income, and regulatory clearance. Some small firms may only require a business license to operate. However, nurseries, orphanages, and retirement homes have very complex regulations to be followed.

- The medium-sized company category comprises companies that emerge from the slow and steady growth of successful small businesses. As a business achieves more revenue, it saves the capital required for premises, equipment, and hiring more employees. That eventually creates the necessary bridge for medium-sized businesses to become corporations or large companies.

\subsection{Objectives and Purposes of the study}

There are several objectives and purposes associated with the study on MSMEs. These are:

- Provide relevant information to governments and industries on the importance of MSMEs to ensure their growth. One of the purposes of the study is to increase the awareness of the governments and industries in developing and developed countries about the MSMEs role in all economic sectors;

- Identify the main problems that MSMEs are facing, including access to financial and human resources. Another important purpose of the study is to identify these problems and propose possible solutions to them based on the experience achieved by others;

- Identify the main operational problems that MSMEs are facing. The purpose of the study is to identify possible actions to be implemented to reduce these problems to the minimum;

- The current situation that MSMEs face in a select group of countries and regions and their experience in dealing with it. The purpose of the study is to encourage other governments and the industry to increase their support for the establishment and operation of new MSMEs in all economic sectors.

\subsection{Significance and Benefit of the Study}

The information provides by the study on the current development of MSMEs in a select group of countries and regions will allow governments and the industry sector to have access to updated information on the role that MSMEs in the economic growth in these countries and regions. The study identifies the main problems and difficulties MSMEs need to overcome to ensure their economic growth.

\section{Difficulties in the MSMEs Access to Financial and Human Resources and Their Operations}

Due to the limited size of many MSMEs, they have difficulty accessing financial and human resources "that would make them more productive, including talented individuals with the latest knowledge of technology, finance, and managerial practices" (Albaz et al., 2020).

The MSMEs operation, in many cases, is not exempt from problems. The main problems related to MSMEs operation are, among others, the following: 
- Digital gap;

- Access to financial resources due to the credit system bureaucracy and the size of the company;

- Informality;

- Limited capital for the purchase of equipment;

- Non-operational guarantee system.

Given the challenges facing MSMEs in several countries, most of them have created a government agency to support growth in this type of company. However, these government agencies' activities aredifficult to be implemented due to the specific MSMEs' market needs, the small scale of their businesses, and the diversity of situations that should be faced (Albaz et al., 2020).

One of the most important MSMEs challenges is access to financial resources. "The International Finance Corporation (IFC) estimates that 65 million firms, or $40 \%$ of formal MSMEs in developing countries, have an unmet financing need of US\$5.2 trillion every year, which is equivalent to 1.4 times the current level of the global MSME lending" (World Bank, 2020). The financial gap share per region is as follow:

- East Asia and Pacific accounts for the largest share with $46 \%$ of the total global finance gap;

- Latin America and the Caribbean, with $23 \%$ of the total global finance gap;

- Europe and Central Asia, with $15 \%$ of the total global finance gap.

Based on the information mentioned above, it can be stated that Latin America and the Caribbean, the Middle East, and North Africa regions are the ones with the highest percentage of the finance gap. For this reason, about half of formal MSMEs do not have access to formal credit. "The financing gap is even larger when micro and informal enterprises are taken into account" (Work Bank, 2020).

Due to their limited size and poor government business policies, MSMEs in developing countries suffers from insufficient available public and private institutions for developing a skilled class of businesspersons and workers, register a low income, and pay lower salaries than big companies. It is more difficult for MSMEs to get affordable, adequate, and long-term credit than large firms (Beck, 2007). The question to be asked is why? The possible answers to this important question are the following:

- First, due to macroeconomic and socio-political instabilities in many developing countries, central banks in these countries usually have to enforce higher interest rates to compensate for the low confidence in the domestic currency;

- Second, capital exports reduce opportunities for credit expansion in domestic currency. Any credit expansion in domestic currency and the corresponding creation of monetary wealth leads to capital exports and a weakening of the currency's external value, something that the central bank cannot accept. That leads to very strict credit rationing and a lack of credit;

- Third, the lack of collateral keeps interest rates, especially high, and credit supply low for MSMEs;

- Fourth, sometimes the level of the credits requested by MSMEs to expnd their activities or to carry out the production of new products or provide new services are too small to be attractive for central or large banks;

- In many developing countries, their banking systems are inefficient, and for this reason, they need high-interest rate ranges (Herr \& Nettekoven, 2017).

It is a well-known phenomenon that the number of MSMEs increases in economic crises because the unemployment level increases, and the poor people are forced to find what to do to survive. Much of MSMEs, particularly microenterprises, are created for this reason, mainly in the informal sector. On the other hand, during economic growth, many of these MSMEs disappear, particularly the micro and small firms, because they provide bad working conditions, the owners exploit themselves, or, compared with the national standard, they pay extremely low wages (Herr \& Nettekoven, 2017). The following are some of the main reasons for the failure of MSMEs:

- Lack of access to the financial market;

- Limited access to the market;

- Lack of skilled workers or poor access to public and private institutions for the development of workers skill ;

- Restricted access to new and advanced technology and equipment;

- Reduced access to information vital to have strong and affective business management; 
- Absence of business management skills.

\section{Micro, Small, and Medium-Sized Enterprises in the European Union}

According to the Fact Sheets on the European Union (EU) entitled "Small and medium-sized enterprises" (2020), in the EU, MSMEs make up 99\% of all businesses registered. In 2015, some 23 million MSMEs in the EU generated around $€ 3.9$ trillion in value-added and employed 90 million people, constituting an essential entrepreneurial spirit and innovation source, which are crucial for EU companies' competitiveness at regional and world level. "In 2018, MSMEs employed $66.4 \%$ of the EU workforce. The EU policy for MSMEs aims to ensure that the EU policies and actions are small business-friendly and contribute to making Europe a more attractive place to set up a company and do business" (Small and medium-sized enterprises, 2020).

This EU policy reflects the following principle: Europe's economic success depends largely on MSMEs' growth, reaching the maximum of their potential. MSMEs "contribute more than half of the total value added in the non-financial business economy and provided $80 \%$ of all new jobs in Europe in the past five years", according to Structural Business Statistics (Eurostat).

However, MSMEs are often confronted with market imperfections, one of the main reasons why MSMEs frequently have difficulties obtaining capital or credit at the beginning of their activities. Indeed, due to the specific characteristics and size of many MSMEs, financial markets have often failed to provide MSMEs with the financial resources they need to carry out their activities without difficulties and restrictions. Undoubtedly, some progress has been made over the last few years in improving the EU availability of supportingMSMEs activities through the provision of loans, guarantees, and venture capital. The European Investment Bank (EIB) and the European Investment Fund (EIF) have increased their operations in supporting MSMEs activities (Gouardères \& Horl, 2017).

However, the Small Business Act (SBA) still identifies access to financeby individual MSME as the second-largest problem faced by this type of firm. In November 2011, the European Commission (EC) "proposed an action plan to improve access to finance for MSMEs (COM(2011) 0870). The action plan includes policy initiatives to ease access to venture capital markets for MSMEs. The EC monitors developments in MSMEs' access to finance through the joint Commission/European Central Bank Survey on the access to finance of enterprises" (Gouardères \& Horl, 2017). Due to their restricted access to financial resources, MSMEs have limited access to new technologies or innovations. Therefore, support for MSMEs is one of the EC's priorities for economic growth, job creation, and economic and social cohesion within the EU.

The new definition adopted by the EU on MSMEs introduces three different categories of firms. Each category corresponds to a type of relationship which an enterprise might have with another. In general, most MSMEs are autonomous since they are either completely independent or have one or more minority partnerships (each less than $25 \%$ ) with other enterprises. In case that it is holding to no more than $50 \%$, the relationship is deemed to be between partners. Above that ceiling, the companies are linked. Depending on the category in which the enterprise fits, it may have to include data from one or more other firms when calculating their own data (The new SME definition. User guide and model declaration, 2018).

According to the new EU definition of MSMEs, it is "any entity engaged in an economic activity, irrespective of its legal form." It reflects the terminology used by the European Court of Justice in its decisions about what they consider an MSME. Thus, according to the European Court Justice decision, self-employed, family firms, partnerships, and associations regularly engaged in economic activity may be considered an MSME. The reason is simple. Its economic activity is the determining factor, not the legal form adopted (The new SME definition. User guide and model declaration, 2018).

The main factors used for the classification of a company in micro, small, and medium-sized firms are the number of employees and the annual turnover or annual balance sheet total (see Table 1). 
Table 1. Types of MSMEs

\begin{tabular}{lccc}
\hline Company category total & Employees & Annual Turnover & Annual balance sheet \\
\hline Medium-sized & $250 \leq$ & $€ 50 \mathrm{~m} \leq$ & $€ 43 \mathrm{~m} \leq$ \\
Small & $50 \leq$ & $€ 10 \mathrm{~m} \leq$ & $€ 10 \mathrm{~m} \leq$ \\
Micro & $10 \leq$ & $€ 2 \mathrm{~m} \leq$ & $€ 2 \mathrm{~m} \leq$ \\
\hline
\end{tabular}

Source: EU.

The above ceilings apply to the figures for individual firms only. A firm that is part of a larger grouping may need to include employee/annual turnover/annual balance sheet data from other firms that belong to the group too.

Without a doubt, MSMEs add dynamism and flexibility to any country's economy due to the development, contribution to increasing competitiveness resulting in higher efficiency, and faster and less expensive adjustments to economic shocks or rapid market changes.

People around the world have been practicing varying techniques for MSMEs development. But surprisingly, the MSMEs' role in economic growth in many countries, particularly in developing countries have not received the necessary government attention of their dominant presence in the market. Historically, politicians and budinessmen and economists emphasized establishing larger corporations as a reliable driving force for the successful growth in many developing country, reflecting their experience in replicating developed countries' success but ignoring the global market's specific characteristics of the market and evolution. That is a wrong approach that needs to be changed.

\subsection{Micro, Small, and Medium-Sized Enterprises Classification used by the World Bank}

The World Bank relies on country standards to classify MSMEs based on the number of employees, total assets, and annual sales. This classification is the following:

- Micro enterprises are defined as individuals/firms with total assets less than US\$100,000, total sales less than US\$100,000, and employ less than ten persons;

- Small enterprises are individuals/firms with total assets or annual sales between US\$100,000 and up to US\$3 million and employ between 10 and 50 persons;

- Medium-sized enterprises are individuals/firms with total assets of more than US\$3 million up to US\$15 million and employ between 50 and 300 persons.

A key area of the World Bank Group's work is to improve MSMEs' access to finance and find innovative solutions to unlock sources of capital. The World Bank (2020) provides the following services, among others, to MSMEs:

- Financial sector assessments to identify areas of improvement in regulatory and policy aspects to facilitate MSMEs access to the financial market;

- Support initiatives related to the development of an appropriate environment for the design and establishment of credit guarantee schemes to support MSMEs activities;

- Improving credit infrastructure to allow greater MSMEs access to the financial market;

- Policy and analytical work, and other advisory services in support of MSMEs finance activities;

- Knowledge management tools and the publication of good practices, successful models, and appropriate policy frameworks related to MSMEs' activities.

\subsection{Micro, Small and Medium-Sized Enterprises in the North American Region}

In the North American region (Canada and the USA), "Canada defines a small business as one with fewer than 100 paid employees and a medium-sized business with at least 100 and fewer than 500 employees" (Wikipedia Small and medium-sized enterprises, 2020). In Canada, the percentage of employment for type of MSMEs are the following:

- $\quad$ Small-sized firms: $88.2 \%$;

- $\quad$ Medium-sized firms: $1.6 \%$;

- Large-sized firms: 0.1\%. In total, MSMEs employed around 89.9\% of employees.

"Canadian high-growth firms are present in every economic sector and are not just concentrated in knowledge-based industries. In terms of employment, the highest concentrations of high-growth firms in Canada during the 2006-2009 
period were in construction, business, building and other support services (4.6\%), professional, scientific, and technical services (4.5\%)" (Wikipedia Small and medium-sized enterprises, 2020).

Corporations tax in Canada is $29 \%$ at the federal level. "Canadian controlled private corporations receive a $17 \%$ reduction in the tax rate on taxable income from active businesses up to US $\$ 500,000$. This small business deduction is reduced for corporations whose taxable capital exceeding US\$10 million and is completely eliminated for corporations whose taxable capital exceeds US\$15 million" (T2 Corporation - Income Tax Guide - Chapter 4, 2014). It has been estimated that Canadian MSMEs' sales value over the coming ten years will be almost US\$2 trillion. That amount is twice as large as the top 1,000 Canadian pension plans' assets and approximately the same size as Canadian annual GDP, according to Equicapita (2014).

In the USA, MSMEs are the backbone of the American economy, with 30 million companies. This type of firm accounts for nearly two-thirds of net new private-sector jobs created in recent decades. One characteristics of US MSMEs is that firms dedicated to export tend to grow faster, create more jobs, and pay higher wages than similar businesses that do not, according to the Office of the United States Trade Representative- Small Business (2020).

The Small Business Administration sets small business criteria based on industry, ownership structure, income, and employee number. In some circumstances, the number of MSMEs employees may be as high as 1,500, although the cap is typically 500 (United States Small Business Administration "Size Standards, 2011). Both the USA and the EU generally use the same threshold of fewer than ten employees for small enterprises. In the USA, according to the American Council for an Energy-Efficient Economy (2017), small and medium-sized manufacturers are referred to as SMMs. The US Department of Energy classifies SMMs "as having gross annual sales below US $\$ 100$ million, fewer than 500 employees at the plant site, and annual energy bills more than US\$100,000 but less than US\$2.5 million" (Industrial Assessment Center Small-Mid Size Manufacturer Criteria, 2017).

When it comes to tax reporting, the US Internal Revenue Service (IRS) "does not categorize businesses into SMEs. Instead, it separates small businesses and self-employed individuals into one group and large to mid-size businesses into another. The IRS classifies small businesses as companies with assets of US\$10 million or less and large businesses as those with over US\$10 million in assets" (Liberto, 2020).

\subsection{Micro, Small and Medium-sized Enterprises In Russia}

MSMEs are vital to the future of the Russian economy. The MSMEs classification in Russia is shown in Table 2.

Table 2. MSMEs classification in Rusia

\begin{tabular}{lll}
\hline Type of enterprise & Revenue $(\boldsymbol{€}$ million) & Number of employees \\
\hline Medium & $10-25$ & $101-250$ \\
Small & $1.5-10$ & $15-100$ \\
Micro & $<1.5$ & $<15$ \\
\hline
\end{tabular}

Source: Small and Medium Entrepreneurship in Russia (2013).

As of March 2019, there were 6.2 million MSMEs in Russia, an increase of 3.9 fold since 2006, employing 15.8 million people, a decreased of 7.1\% concerning the period 2005-09. One important characteristic of the MSMEs in Russia is that $95 \%$ of this type of firm are micro-enterprises, accounting for $47 \%$ of the total employment, and $22 \%$ of Russia's GDP. However, despite various government financing schemes to support credit to MSMEs, the share of MSMEs credit in total business is only $12.6 \%$, which is lower than their contribution to Russia's GDP (22\%) and is half the OECD average (25\%).

Another relevant characteristic of the Russian MSMEs is the following: even though the number of MSMEs in Russia has been growing, their contribution to the economy is still below most BRIC countries and considerably lower than in developed economies. In the OECD group, MSMEs account for between $50 \%$ and $60 \%$ of GDP and $60 \%$ of total employment (Gutierrez et al., 2017) (Note 1).

According to the current Russian law, "a firm is deemed small if it meets two criteria - one restricts the number of employees, and another - the ownership structure" (Polischuck). Namely, a small firm's labor force should be below a certain ceiling, which depends on the economic sector. The ceilings by economic sector are the following:

- 100 employee in the industry and construction sectors; 
- 60 employees in the research and development sector;

- 30 employees in trade and services sectors;

- 50 employees in the education and health care sectors.

It is important to single out that "the share in the firm's equity of the central and local governments, non-profits, and other legal entities not involved in running the firm, could not exceed 25\%" (Polischuck). Russian enterprises with less than nine workers are classified as micro-enterprises, while enterprises with up to 200 workers are classified as small-sized enterprises.

According to a study carried out by the European Investment Bank in 2013 entitled "Small and Medium Entrepreneurship in Russia," the participation of MSMEs in the Russian GDP is significantly lower than in developed countries but incomparably higher than in developing countries.

In the industrial structure's case, the Russian MSMEs segment shows the underdevelopment of certain industries. Around $57 \%$ of MSMEs turnover falls within the trade sector. The manufacturing sector accounts for $11.5 \%$ of total turnover, followed by the construction sector with $11.0 \%$, and real estate with $9.7 \%$. Together these four sectors amount to approximately $90 \%$ of MSMEs turnover (89.2\%). If the regional structure is considering, then the Russian MSMEs segment shows the uneven distribution of MSMEs turnover within the country. Approximately $80 \%$ of MSMEs revenue comes from firms located in the European part of Russia, with $48 \%$ coming from the Central and North West Federal Districts. Additionally, MSMEs located in Moscow and Saint Petersburg generate 18\% and 7\% of total revenue, respectively (Small and Medium Entrepreneurship in Russia, 2013).

One of the key constraints to MSMEs development in Russia is the low accessibility to the financial market.

"Key financial instruments available on the Russian MSMEs market are bank loans, leasing, factoring, microfinance, and private equity. The most popular source of MSMEs financing is bank loans (27\%), followed by borrowings from relatives and friends (19\%) and trade credit (17\%). Leasing, factoring, and others are not widely popular" (Small and Medium Entrepreneurship in Russia, 2013).

The most common purposes of using external financing to support the activities carried out by MSMEs are for investment reasons (purchase of equipment and vehicles, among others) and working capital 55\% and $47 \%$, respectively. None of the other purposes exceeded 10\% (Small and Medium Entrepreneurship in Russia, 2013).

It is expected that the share of total MSMEs financed by institutional investors and the total number of MSMEs will increase in Russia during the coming years. To support that growth the Russian government will allocate US\$6.6 billion for the implementation of a six-year National Project on MSME and Individual Entrepreneurship Support. The main measures envisioned in the National MSME Project to improve MSMEs access to the financial market include:

- Simplifying access to subsidized finance and increasing its volume;

- Facilitating access to capital markets for MSMEs;

- Improving access to leasing instruments;

- Facilitating access to micro-finance and crowdfunding.

The Central Bank of Russia developed a roadmap for facilitating MSMEs access to the financial market to support the National MSMEs Project's implementation. "For 2019-2024, the government will provide RUB 261.8 billion (US\$4 billion) for improving MSMEs access to finance, with a significant portion going to subsidized bank lending. The Russian government can play a more decisive role in supporting the development of the MSMEs financing ecosystem by providing technical assistance and access to technology-based platforms for commercially oriented non-bank financial intermediaries" (Gutierrez et al., 2019).

Without a doubt, MSMEs development is an important element for the Russian economy to achieve high economic growth and productivity. In the developed economies, MSMEs are at the core of the private sector, contributing to job creation and growth (Gutierres et al., 2019). In Russia's case, the situation is quite different. In Russia, there is a high presence of State-owned enterprises, which tend to be less productive than private firms. Therefore, developing the MSME sector can increase productivity and a positive impact on the Russian economy. For this reason, "creating conditions for MSMEs to develop and grow is crucial for the Russian economy to expand and become more productive. Access to finance is critical for the growth of MSMEs as it allows firms to innovate, improve efficiency, expand to new markets, and create new jobs" (Gutierrez et al., 2019).

Although the number of MSMEs in Russia is increasing, they face several challenges, including a complex credit situation and the limited government efforts to improve the business environment. However, the greatest threat to 
MSMEs "is the underdeveloped legal and administrative infrastructure, which is highly susceptible to corruption. Even though the government passed new laws restricting the number of annual inspections for businesses and required that regulatory officials obtain prior approval from the prosecutor's office to conduct said inspections, small businesses see the entire legislative apparatus as corrupt" (Furtuna \& Ruvinskayay, 2012).

\subsection{Micro, Small and Medium-Sized Enterprises in India}

Indian economy is expected to register a steady growth during the coming years. The manufacturing industry holds an important key position in the Indian economy. It contributes in a meaningful manner to the Indian GDP and offers employment opportunities for the countrymen (Archana, 2018).

The number of India's MSMEs is the largest in the world after China. MSMEs provides a wide range of services and is engaged in manufacturing over 6,000 products of differenttypes. The definition of who qualifies as an MSME in India has changed based on investment and income. The new definition announced on May 13, 2020, will apply to both manufacturing and services MSMEs in India.

According to Archana (2018), manufacturing enterprises are called in India all companies engaged in the manufacturing "or production of goods relating to any industry specified in the first schedule to the Industries (Development and Regulation Act of 1951), or employing plant and machinery in the process of value addition to the final product having a distinct name or character or use. The manufacturing enterprise is defined in terms of investment in plant and machinery." On the other hand, services companies in India are defined as firms engaged in "providing or rendering services defined in equipment investment" (Archana, 2018).

India's dominant sector is the service sector, which employsapproximately 50 million workers. In contrast, the manufacturing sector could only pull off half that number. "Most of the employment comes from unregistered enterprises, with hesitations and avoidance of the difficult registration process quite evident. The saying "small things make the largest impact" holds true for MSMEs in India, where small enterprises had a fixed asset value of over two trillion Indian rupees. With more infrastructural input and a simplified registration process, and receiving benefits from the government, MSMEs in the country are destined to go a long way" (Statista Research Department, 2020).

According to India Briefing (2020), the new definition expands the types of firms that can now avail themselves of MSME status and enjoy linked benefits. The types of firms are the following:

- Micro-sized firms: companies with investment up to US\$132,521 and an income up to US\$662,715;

- Small-sized firms: companies with investment up to US\$1.3 million and an income up to US\$6.62 million;

- Middle-sized firms: companies with investment up to US\$2.6 million and income up to US\$13.24 million.

The number of MSMEs across India in 2020 by type is shown in Figure 1.

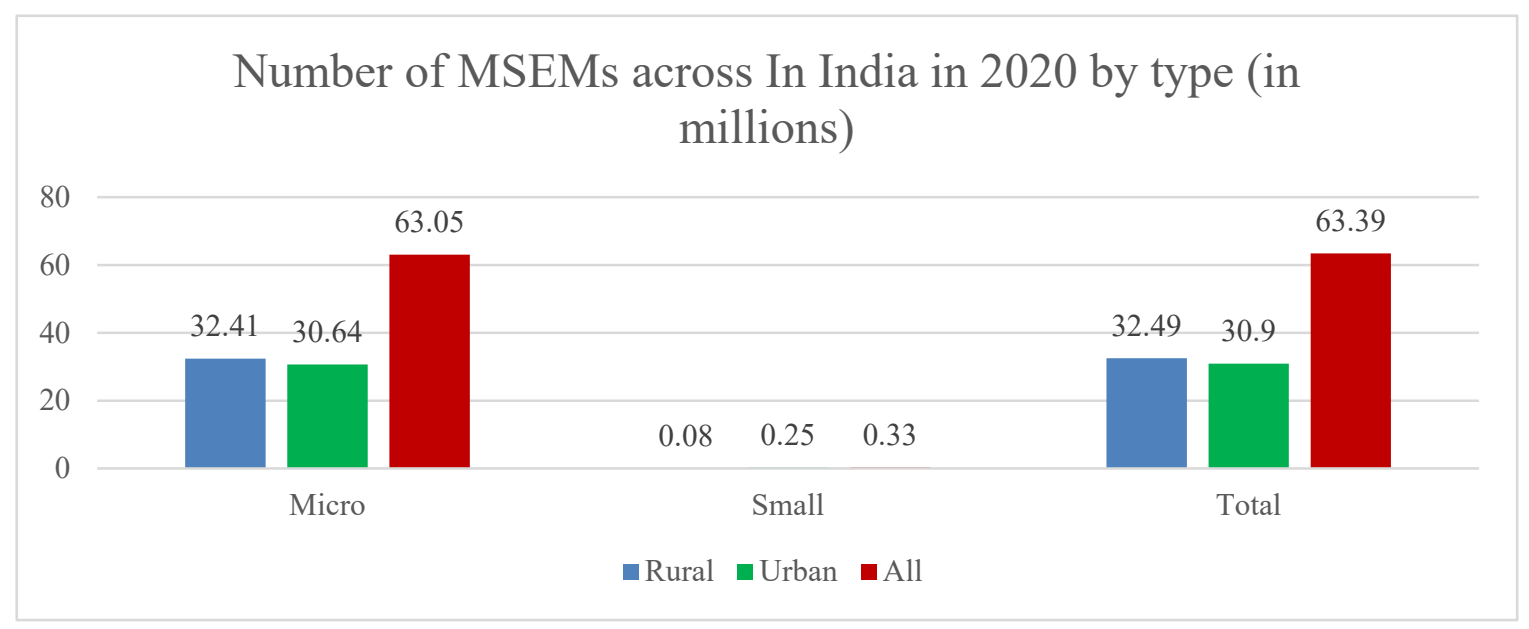

Source: Statista 2020

Figure 1. Number of MSMEs across India in 2020 by type 
In the financial year 2020, the country's total number of MSMEs was more than 63 million. The majority comprised micro-sized firms, "with a higher number in rural areas than urban parts of the country. More often than not, these were run by the owners with little or no support and revenue earnings as a priority" (Statista Research Department, 2020). Without a doubt, MSMEs are vital for the Indian economy, the country's market, and the generation of employment.

India's federal government has adopted various schemes and measures to allow MSMEs easier access to financial funds. These schemes and measures aim to make MSMEs more competitive in the Indian and world market, including measures and schemes to ensure product quality, especially those for exports, technology up-gradation, incubation, credit-linked capital subsidy, among others.

Some of the other concessions available in India to support MSMEs activities are listed below:

- "Collateral free loans from banks;

- Fifty percent subsidy on patent registration;

- One percent exemption on the interest rate on overdraft;

- Concession on power utility bills;

- Eligible for industrial promotion subsidy;

- Protection against delayed payments;

- Reimbursement of ISO certification charges" (India Briefing, 2020).

MSMEs employ $40 \%$ of India's workforce, estimated to be around 80 million people. Approximately 1.3 million MSMEs contribute to $45 \%$ of India's manufacturing output, $40 \%$ of total export, and about $17 \%$ of India's GDP. If MSMEs are provided with the right support, they can spread industrial growth throughout the country. For this reason, the government aims to increase the manufacturing sector's growth within the MSMEs between $12 \%$ and $14 \%$ per annum and increase its GDP share to $25 \%$ by 2025 (Archana, 2018).

The opportunity areas for the expansion of MSMEs in India are, according to Micro, Small, and Medium Enterprises in India- An Explainer (2020), the following:

- Telecommunications;

- Healthcare;

- Electronics;

- Information technology;

- Pharmaceutical;

- Chemical;

- Automotive;

- Renewables;

- Gems and jewelry;

- Textile;

- Food;

- Agriculture.

\subsection{Micro, Small and Medium-Sized Enterprises in China}

China's banking industry and regulatory authority define micro and small businesses using the same standard set by the National Bureau of Statistics of China. Small businesses are based on the industry sector, the number of employees, annual sales, and total assets. Small firms are companies with annual sales of less than RMB 30 million and with a number of employees ranging from as low as 100 (in the wholesale industry) to as high as 600 (in the construction industry).

China's MSMEs made important contributions to the country's economic development during the 2014-2018 period. At the end of 2018, the number of MSMEs reached 18.07 million (115\% growth from 2013), making up 99.8\% of all legal entities, according to a report on China's fourth economic census released by the National Bureau of Statistics. The report said MSMES employed around 233 million people, accounting for $79.4 \%$ of nationwide enterprise employees. The total annual operating revenue of MSMEs stood at 188.2 trillion yuan (about US\$26.9 trillion) in 2018, 
accounting for $68.2 \%$ of that from all companies in the country, according to a report on China's SMEs as Important Contributors to the Economy (2019).

The Xinhua press indicated nearly $40 \%$ of MSMEs operated in the country's central and western regions. In contrast, those in the eastern region kept the advantage in generating operating revenue, according to the report mentioned above.

The following features are identified by Salient Features of the Micro, Small and Medium Enterprises Development Act of 2006:

- Employment of limited people;

- Minimal capital investment;

- Easy entry and exit pathways;

- Reliance on workers being trained on the job;

- High representation of women;

- Use of unwritten or informal employee contracts with little or no appreciation of industrial relations, workers' rights, or occupational health and safety;

- Work in conjunction with the formal sector, such as through the supply of products or equipment repair.

MSMEs add dynamism, flexibility, and growth to the China's economy through the new firm establishment, contributing to increase competitiveness resulting in higher efficiency, and allowing faster and less expensive adjustments to economic shocks or rapid market changes. Specific regulations related to starting a business, closing a business, registering property, labor regulations, contract enforcement, and investor protection could either enhance or constrain MSMEs' productivity and growth. In some cases, the costs mentioned above may be too high, providing disincentives for MSMEs to grow and expand into medium-sized companies.

Doing business in China, particularly in the case of MSMEs, is not without risk. Many of the current failings of MSMEs activities are due to the lack of access to reliable power and labor forces, as well as financial credit, causing many businesses to experience tremendous hardships. According to Clarke (2016), there are a few other areas that are extremely important to consider, as well:

- Intellectual Property (IP): one such risk, particularly important for smaller companies, is IP and law enforcement. There has been some progress on the enforcement of IP rights within China. However, it is still critically important for smaller companies to be aware of and take steps to ensure their rights are protected;

- Finding the Right Partner: finding the right local partner becomes critical for a business proposal's success .It is important to ensure that your business proposal ia aligned with the interest of the local partner and people;

- Access to Funding: While a foreign investor may be the source of the funding, it is important to know what current Chinese MSMEs can do to find the necessary capital to operate without difficulties (Clarke, 2016).

\section{Conclusion}

Without a doubt, MSMEs comprise the major share of business entities worldwide. In developing countries, MSMEs contribute to most economic activities, but sometimes their role has not been fully understood by politician and businesspeople. They are vital forces for employment creation, economic growth, poverty alleviation, and promoting inclusive and sustainable development.

MSMEs have played an important economic role in many countries all over the world in the past. To continue playing this role in the future, governments should increase their support to MSMEs activities in creating jobs, facilitate access to financial resources and the market, and improving livelihoods. Why? MSMEs depend more than ever on a supportive business environment, including backing for access to the financial market, information, and the national, regional, and world markets.

Without a doubt, MSMEs have a larger impact on the economy of developing and developed countries alike. In addition to their role as the pillar in many countries' economies, MSMEs are an important component of large enterprises' supply chains. For this reason, their security should be as much concern to these enterprises as their own.

Finally, it is important to stress the following: the participation of MSMEs in international trade "has remained limited for numerous reasons. These include lack of relevant skills, lack of knowledge about international markets, non-tariff barriers, cumbersome regulations and border procedures, and limited access to finance, particularly trade finance" 
(World Trade Organization Small business and trade, 2020). The smaller the MSMEs are, the greater the challenges faced in participating in international trade.

\section{References}

Archana. (2018). What is Micro, Small, and Medium Scale Enterprises in India? Retrieved from https://www.goodreturns.in/classroom/2018/02/what-is-micro-small-medium-scale-enterprises-india/articlecont ent-pf10871-668731.html

Albaz, A., Dondi, M., Rida, T., \& Schubert, J. (2020). Unlocking growth in small and medium-sized enterprises. McKinsey \& Company.

American Council for an Energy-Efficient Economy. (2017). Targeting Small and Medium-Sized Manufacturers. Retrieved April 3, 2017.

Beck, T. (2007). Financing constraints of SMEs in developing countries: Evidence, determinants and solutions (Tilburg University). $\quad$ Retrieved October 11, 2017, from https://pure.uvt.nl/portal/files/1107677/Financing_Constraints_of_SMEs.pdf

China National Bureau of Statistics. (2018).

Clarke, C. (2016). Small and Medium Enterprises in China. Nolasia, Business in China, 2016.

$\operatorname{COM}(2011) 870$ final. (2011). Communication from the Commission to the Council, to the European Parliament, to the Committee of the Regions, and the European and Social Committee; An action plan to improve access to finance for SMEs $\{$ SEC(2011) 1527 final $\} ; 2011$.

Equicapita. (2014). Who Will Buy Baby Boomer Businesses? (PDF); May 2014.

Furtuna, F., \& Ruvinskayay, A. (2012). Small Businesses in Russia: Drowning in a Sea of Giants (Wharton, University of Pennsylvania, USA).

Gouardères, F., \& Horl, S. (2017). Small and medium-sized enterprises; Fact Sheets on the European Union, European Parliament.

Gutierrez, E., Klepikova, E., \& Levitanskaya, K. (2019). World Bank. 2019. Expanding Access to Financing for Micro, Small and Medium-Size Enterprises in Russia by Leveraging Innovative Financial Solutions. World Bank. https://doi.org/10.1596/32405

Herr, H. A. N. S. J. Ö. R. G., \& Nettekoven, Z. M. (2017). The role of small and medium-sized enterprises in Development. Friedrich ebert stiftung, Retrieved on November, 5, 2019.

India Briefing. (2020). Micro, Small, and Medium Enterprises in India - An Explainer; 2010.

Industrial Assessment Center Small-Mid Size Manufacturer Criteria. (2017). Industrial Assessment Centers. Retrieved April 3, 2017.

Liberto, D. (2020). Small and Mid-size Enterprise (SME). Investopedia, 2020.

Office of the United States Trade Representative. (2020). Small Business. 2020.

Polishchuk, Leonid; Small Businesses in Russia: Institutional Environment Center for Institutional Reform and the Informal Sector (IRIS) at the University of Maryland at College Park. Retrieved from https://rsfdgrc.hse.ru/data/792/617/1237/SSRN-id260042.pdf.

Report: China's SMEs important contributors to economy. (2019). Xinhua, China Daly, Hong Kong; 2019. Retrieved from https://www.chinadailyhk.com/articles/246/77/157/1577593659496.html

Small and medium-sized enterprises. (2020). Fact Sheets on the European Union. European Parliament.

Small and Medium Entrepreneurship in Russia. (2013). European Investment Banks. Luxemburg.

Statista Research Department. (2020). Number of MSMEs across India in financial 2020 by type.

$\begin{array}{lllll}\text { Structural } & \text { Business } & \text { Statistics } & \text { (Eurostat). } & \text { Retrieved }\end{array}$ http://epp.eurostat.ec.europa.eu/portal/page/portal/european_business/data/database

T2 Corporation - Income Tax Guide - Chapter 4: Page 4 of the T2 return. (2014). Canada Revenue Agency. Retrieved April 27, 2014.

The new SME definition. User guide and model declaration. (2018). European Commission; 2018. 
The World Bank. (2020). Small and medium enterprises (SMEs) finance: Improving SMEs' access to finance and finding innovative solutions to unlock sources of capital.

United States Small Business Administration. (2011). Size Standards. Retrieved August 21, 2011.

Wikipedia Small and medium-sized enterprises. (2020).

World Trade Organization. Small business and trade. (2020).

\section{Notes}

Note 1. "World Bank. 2019. Expanding Access to Financing for Micro, Small and Medium-Size Enterprises in Russia by Leveraging Innovative Financial Solutions. C World Bank."

Note 2. MSME's which have no access to bank financing due to various obstacles, for example, high borrowing cost, and lack of collateral, among others.

Note 3.Persons who commence their own business - start-up project.

\section{Copyrights}

Copyright for this article is retained by the author(s), with first publication rights granted to the journal.

This is an open-access article distributed under the terms and conditions of the Creative Commons Attribution license (http://creativecommons.org/licenses/by/4.0/). 